\title{
Sustainable rural electrification planning in developing countries: A proposal for electrification of isolated communities of Venezuela
}

\author{
A. López-González ${ }^{\mathrm{a}, \mathrm{b}, \mathrm{c}, *}$, L. Ferrer-Martía ${ }^{\text {, B. Domenech }}{ }^{\mathrm{d}}$ \\ ${ }^{a}$ Institute of Industrial and Control Engineering, Universitat Politècnica de Catalunya, BarcelonaTech, Spain \\ ${ }^{\mathrm{b}}$ Institute of Sustainability, Universitat Politècnica de Catalunya, BarcelonaTech, Spain \\ ${ }^{c}$ Socioeconomic Center of Petroleum and Alternative Energies, Universidad del Zulia, Venezuela \\ ${ }^{\mathrm{d}}$ Serra Húnter Fellow, Institute of Industrial and Control Engineering, Universitat Politècnica de Catalunya, BarcelonaTech, Spain
}

\section{A R T I C L E I N F O}

\section{Keywords:}

Rural electrification planning

Renewable energy technologies

Sustainability dimensions

Energy trilemma

Venezuela

\begin{abstract}
A B S T R A C T
Small-scale renewable energy technologies offer impoverished rural communities in developing countries the ability to overcome extreme poverty and improve their living conditions. Unfortunately, most presented frameworks for rural electrifications have not adequately addressed the three cores of energy trilemma. This paper proposes a methodology of rural electrification planning to overcome the three cores of the energy trilemma (environment, security and equity), considering four sustainability dimensions: environmental, technical, socioeconomic and institutional. The proposal is based on a review of the Venezuelan program "Sembrando Luz" ("Sowing Light"), developed between 2005 and 2013, through visits to 28 beneficiary communities. A set of lessons learned were used to define the methodological proposal developed here. This proposal establishes specific objectives for the achievement of sustainability in rural electrification programs, through a novel conceptual framework, valid for the achievement of universal access anywhere in the world. In addition, hierarchical criteria and a projects classification are proposed, which finally enables a projects portfolio to be designed according to the technical and financial conditions available in each country. As a case study, the planning methodology is applied to 2,269 isolated communities in Venezuela that still lack electricity. The methods and conclusions of this work are intended to be a contribution to the improvement of rural electrification programs with renewable energy in other countries of the developing world.
\end{abstract}

\section{Introduction}

Currently, about a fifth of the world's population remains without electricity, in the poorest and geographically remotest areas of developing countries (REN21, 2016). Access to reliable, sustainable and modern electricity (SEforAll, 2016), is indispensable for achieving development goals, such as eradicating extreme poverty (Terrapon-Pfaff et al., 2014), increasing food production, accessing safe drinking water and public health services, raising economic opportunities, gender equity, and quality education (UN, 2012). In recent years, the overall electrification rate has increased less than 1\% year-on-year (IEA, 2014), the same as the world population growth rate. This overall electrification rate is mainly due to the expansion of urban networks and, to a lesser extent, to new access points in rural communities.

Latin American countries have shown a significant increase in rural electrification rates due to the direct intervention of the governments in the planning, financing and execution of national rural electrification programs. This situation is particularly noteworthy in cases such as Brazil (Pereira et al., 2010) (Slough et al., 2015), Bolivia (Peredo Echazú et al., 2010), Ecuador (MEER, 2017) (Tech4CDM, 2009) and Venezuela (López-González et al., 2017b). According to the historical record of the Latin American Energy Organization (OLADE), from 2005 to 2014, the electrification rate in South America increased at $0.57 \%$ per year, from $93.16 \%$ to $96.19 \%$ (OLADE, 2018). However, this rate was reduced to $0.27 \%$ from 2014 to 2017 . This is due to the focus on progressively scattered and isolated houses without electricity, increasingly requiring from autonomous Renewable Energy Technologies (RET) electrification systems (Banal-Estañol et al., 2017). Currently, 22 million people are still excluded from access to electricity, particularly in Peru, Colombia, Guatemala, Haiti, Bolivia and Nicaragua (REN21, 2016). For example, in Peru only the direct intervention of the state managed to increase the year-on-year rural electrification rate by $60 \%$ (MINEM, 2012). In the remaining countries, difficulties for rural electrification are mainly due to houses dispersion over large territories,

\footnotetext{
* Corresponding author. Av. Diagonal 647, Pavilion F, Floor 0, 08028 Barcelona, Spain.

E-mail address: a.lopez@upc.edu (A. López-González).
} 
with low population density and few access roads and communications (Doll and Pachauri, 2010). In addition, some other issues like household income and the country's level of economic development are also important in the difficulty to reach a universal access in this region (Jimenez, 2017).

The difficulty for achieving universal access in developing countries is evidenced by the three cores of the so-called energy trilemma (World Energy Council, 2016). The need for providing access to energy to everybody in the world ("energy equity") runs counter to the need for reducing $\mathrm{CO}_{2}$ emissions ("environment"), typically caused by thermoelectric generation. Simultaneously, the energy supplied to communities must meet the minimum power needs of the population and must be reliable (Bhatia and Angelou, 2015). Therefore, access to energy must be safe in terms of guaranteeing the present and future demand ("energy security"). According to Sovacool and Drupady (2016), smallscale renewable technologies offer rural population the ability to overcome extreme poverty and raise living standards. In this sense, they are a suitable alternative for the electrification of almost inaccessible rural communities in developing countries, by means of isolated systems and/or microgrids, using wind and solar technologies.

Between 2007 and 2016, the installed capacity of renewable energybased technologies (RET) for off-grid rural electrification increased fivefold (IRENA, 2017a). These technologies provide electricity to 60 million houses and 300 million people (IRENA, 2017b). However, according to the International Energy Agency (IEA, 2014), the investment made is only half of that needed to achieve universal access worldwide. In addition, rural electrification planning needs to encompass broader development benefits such as education, health and income generation, to be in line with rural development policies (Bazilian et al., 2012). Thus, a comprehensive development would help to sustain the immediate impact of each electrification project in the medium and long term (Nguyen and Rieger, 2014). Moreover, it has been shown that successful programs tend to promote economies of scale and standardize processes, the purpose being to ensure that technologies are easier to repair or replace (Sovacool and Drupady, 2016). This is only possible with large-scale planning, where projects and technologies of similar characteristics and dimensions are grouped together.

In Africa, the United Nations SE4ALL program has lead 13 governments in 30 countries to develop Action Agendas for the achievement of universal energy access by 2030 . Each of these countries must develop rural electrification programs, considering that $49 \%$ of the electricity will be supplied from renewable sources (ADB, 2017). This region concentrates 640 million people without access to electricity (ADB, 2017), most in need of proposals and methodologies to plan rural electrification programs. Unlike Africa, in three of the most important developing economies (China, India and Brazil) rural electrification programs have been implemented at a national level through centralized planning, with significant results. First, the Chinese government launched a large-scale program in late 2001, which electrified more than 1,000 municipalities in nine western provinces over a period of 20 months, giving access to almost one million people. The first phase of the plan was completed in June 2003 and reached $20 \mathrm{MW}$ in Solar Home Systems (SHS), $840 \mathrm{~kW}$ in House-sized Wind Turbines (HWT) and $200 \mathrm{MW}$ in Micro-Hydro Power (MHP). The entire investment was covered by a contribution of 240 million dollars from the central government. Subsequently, the projects included 51 hybrid wind-solar microgrids and 670 photovoltaic (PV) microgrids and SHS (Shyu, 2012). In India, the Ministry of New and Renewable Energy, as part of the Jawaharlal Nehru National Solar Mission program, has installed around $200 \mathrm{MW}$ using standardized $250 \mathrm{~kW} \mathrm{PV} \mathrm{minigrids} \mathrm{for}$ rural villages and is planning $800 \mathrm{MW}$ more by 2022 (Thirumurthy et al., 2012).

In South America, the most notable case is Brazil and the program "Luz para todos" ("Light for All") (Pereira et al., 2010). Through this program, between 2003 and 2015, 3.2 million houses were electrified, benefiting 15.6 million people in isolated rural communities, among which priority was given to 35,000 indigenous families in the Amazon territories. $70 \%$ of the financial resources were provided by the government of Brazil, with the rest coming from municipal governments and local electricity companies (Ministério de Minas e Energia, 2015). This program had a very important impact on the electrification index, which grew from $94.5 \%$ in 2000 to $98.7 \%$ in 2012 , while the country is currently close to achieving universal electricity access (Slough et al., 2015). Another interesting case is Bolivia, which increased rural electrification from $33 \%$ in 2005 to almost $70 \%$ in 2015 through a government rural electrification program that included renewable energy as an alternative for the most dispersed and isolated communities (Peredo Echazú et al., 2010). It is estimated that universal access will be reached by 2025 , electrifying the remaining 548,384 houses, from which 50,726 (9.3\%) will get electricity through isolated RET systems (solar, wind and biomass) acquired with government funds (Peredo Echazú et al., 2010). The case of the intergovernmental rural electrification program developed by Venezuela and Cuba in collaboration with Bolivia is particularly noteworthy. In this program, Venezuela contributed 8,000 PV panels (195 Wp), converters and batteries for the electrification of schools located in rural areas, while Cuba provided technical and logistical support for the installation. Through this initiative, video-players and TVs were provided and 827,000 people were taught to read and write. This program led to UNESCO declaring, by the year 2008, Bolivia a country free from illiteracy (BBC, 2008).

Generally, successful programs have drawn on lessons learned from previous experiences, enabling them to develop much more accurate feasibility studies before initiating large-scale projects, as well as expanding the production or distribution of technologies to be used (Sovacool and Drupady, 2016). These examples show that for rural electrification in developing countries, the energy trilemma can only be addressed through the long-term commitment of governments and the execution of plans by Electricity Service Companies (ESC) or Autonomous Authorities of Rural Electrification (AARE). Considering that most developing countries are exporters of natural resources, mainly minerals and oil, as predominant incomes, the fluctuating trends in the prices of these commodities have an adverse impact on the sustainability of government programs, and particularly RET-based rural electrification (Altomonte, 2017). According to López-González et al. (2017a), the Venezuela's case is noteworthy due to the impact of the drop in oil prices, in 2012-2013, on the investment and continuity of the "Sowing Light" program. Similarly, the political changes in Brazil have caused the "Light for All" rural electrification program to be modified towards a decrease in public investment (CELAC, 2018). Therefore, the countries' incomes and political changes have a relevant impact on the success of national rural electrification programs and their design. In order to minimize the negative impacts, institutions as ESC and/or AARE must be financially robust and their main income must not come from electricity supply to rural areas, but from urban, industrial and commercial rates (van Ruijven et al., 2012). Therefore, rural investments are justified through the energy trilemma approach from all aspects of sustainability, not only economic or financial. However, the usual economic protectionism of developing countries, is reflected in large rural electrification national program s, which tend to be based on a state ownership regulative regime at the first stages, as in Brazil (CELAC, 2018), China (Pereira et al., 2011), India (Jebaraj and Iniyan, 2006) and Venezuela (MPPEE, 2013a). However, such countries are characterized by wide and significant cultural differences between territories, so the imposition of homogenous models may possibly result in a management fail. Alternatively, a stated owned system could be initially introduced in the projects, always with a strong community participation, which should then be transferred to the communities and adapted to their cultural and social characteristics.

In this paper, a methodological proposal for sustainable rural electrification planning is developed, considering the energy trilemma from four sustainability perspectives: environmental, technical, socioeconomic and institutional (Brundtland, 1987). This proposal 
establishes specific objectives for the achievement of sustainability in rural electrification programs, through a novel conceptual framework, valid for the achievement of universal access anywhere in the world. In addition, hierarchical criteria and a classification of projects by population and energy resources are proposed, finally defining a projects portfolio according to the technical conditions and the available budget of each country. The criteria are defined based on the visits made in summer 2016 to 28 rural communities benefiting from the "Sowing Light" program developed by the Foundation for the Development of the Electricity Sector (Fundelec, 2015), in Venezuela (Alejandro LópezGonzález et al., 2017b). Therefore, the objective of this paper is threefold: 1) to develop a national planning methodology for developing countries, based on the two most globally accepted concepts regarding sustainable development (sustainability dimensions and energy trilemma); 2) to define a projects portfolio according to a classification by population and energy resources; 3 ) to allow developing countries to have their own projects portfolio to be implemented during time and economic resources availability, so governments can progressively execute projects considering fluctuations in their economies due to the volatility in raw materials prices. Thus, the lessons learned were extracted and incorporated into the methodological proposal. Finally, as a case study and an illustrative example, the planning methodology is applied to 2,269 isolated communities that still lack electricity service in Venezuela, in order to achieve universal access. This proposal is applicable to any other developing country elsewhere in the world.

Electrification planning methods can be classified according to the scale of application: regional project planning or national rural electrification programs. Regional planning generally focuses on the detailed particularities of a set of communities located in a well-defined territory with similar conditions and characteristics. For instance, Falcón-Roque et al. (2017) propose a regional project planning model, which is applied to the Cajamarca province (Peru), a region having very particular and extreme conditions with the lowest electrification rate of the country and very high dispersion of houses within the communities.

Nevertheless, regional planning methodologies are not able to reach good results at a national level if they are directly extrapolated. In this regard, national rural electrification programs do not consist on an extension of regional planning methods, but refer to objectives established at the higher national energy policy level. This mean, global agendas and agreements are the main aspects considered in the objectives of the program for a policy execution in the strategic level.

The reviewed methods for national rural electrification programs focus on the development of large power systems (generation, transmission and distribution) and electrical networks planning issues. Singh and Sharma (2017), reviewed several national planning methodologies, concluding that most of them focus on distribution power systems and performance issues of electrical networks. In contrast, a methodology is here developed to improve national rural electrification programs and assist decision-making, by obtaining a national projects portfolio. Such portfolios have been used in developing countries like Brazil (CELAC, 2018), China (Pereira et al., 2011), India (Jebaraj and Iniyan, 2006) and Venezuela (MPPEE, 2013a). Shyu (2012) made an analysis of Chinas' Township Electrification Program, from a policy perspective but not considering the long term sustainability. Mitra (2006) made an analysis of electricity from renewables on small islands, including Cuba, considering techno-economic aspects. On their behalf, Pereira et al.
(2010) and Slough et al. (2015) made an analysis of Brazil's light for all program, similarly to Shyu (2012). Büyüközkan and Karabulut (2017) proposed a method with a sustainability perspective for better selecting concretely defined energy projects based on multi-criteria decision making, but focussing power generation projects, not rural electrification. Finally, Chaurey and Kandpal (2010) made a techno-economic performance evaluation and monitoring of various PV based decentralized rural projects, considering environmental implications and life cycle analysis. In all these cases, the plans were executed but without a clear and structured methodology to organize decision-making, which is the new insight and contribution of this paper. Hence, the purpose of the proposed methodology is to estimate the investment needs of developing countries for RET-based rural electrification, within national energy programs and policies.

The remainder of the article is organized as follows. Section 2 presents the lessons learned from the analysis of visits to 28 communities of the "Sowing Light" program in summer 2016. Section 3 describes the proposed methodology for sustainable rural electrification planning, developed from the lessons learned. Section 4 shows the implementation of the methodology in the remaining communities without electricity in 6 isolated rural regions of Venezuela. Finally, the main conclusions are summarized in Section 5.

\section{Technical description of "Sowing Light" (Venezuela, 2005-2013)}

Between 2001 and 2013, 1.8 million people throughout the territory gained access to electricity by means of renewable and non-renewable technologies; particularly in municipalities with low population densities and highly scattered housing. Thus, the electrification rate increased from $96.77 \%$ in 2001 to $98.89 \%$ in 2011 and to more than $99 \%$ in 2013 (Instituto Nacional de Estadistica, 2013).

The "Sowing Light" program, whose greatest impact was achieved between 2005 and 2013, started as part of a Program of the Venezuelan Ministry of Electric Energy, aiming to diversify technologies used for electricity supply in order to reach 300,000 non-electrified houses (Massabié, 2008). This program was part of a set of three strategies to expand the electricity coverage: 1 ) expansion of the generating capacity and the distribution network; 2) expansion of the generating capacity through distributed diesel generators; and 3) electrification of rural villages using renewable energy.

The three strategies were implemented by different stakeholders, under the supervision of the Ministry of Electric Energy as regulator of the Electricity Service (RE). The strategy (1) was executed by Corpoelec as ESC; while the strategy (3) was developed by Fundelec as AARE, who occasionally also implemented projects from strategy (2). Note that these stakeholders have been defined according to Haanyika's classification (Haanyika, 2006). Among the 1.8 million people getting electricity access between 2001 and 2013 in Venezuela, 7\% received, directly or indirectly, renewable energy systems under the "Sowing Light" program (strategy 3) (Instituto Nacional de Estadistica, 2013). This program consists of 3 different phases according to the technologies used (De Pablos, 2014): PV panels for electrification of community infrastructures such as schools and health centers (Phase I); SHS for residential electrification (Phase II); Hybrid (wind-PV-diesel-battery) Microgrids (HMG) for electrification of communities up to 40 houses

Table 1

Implemented technologies, by phases, in the "Sowing Light" program (2005-2013).

\begin{tabular}{|c|c|c|c|c|c|}
\hline Phases and technologies & Phase beginning & Scope & Equipment used & W/inhab. & Beneficiaries (2005-2013) \\
\hline (I) PV for community infrastructures & 2005 & Community infrastructures & $1200 W p \& 3840 W p$ & 8 & 130,000 \\
\hline (II) SHS & 2007 & Houses & $300 \mathrm{Wp} \& 600 \mathrm{Wp}$ & 120 & 10,000 \\
\hline (a) HMG & 2009 & Houses \& community infrastructures & $15 \mathrm{~kW}, 26 \mathrm{~kW}, 36 \mathrm{~kW} \& 46 \mathrm{~kW}$ & 305 & 1,800 \\
\hline (b) HWT & 2012 & Houses & $1.5 \mathrm{~kW}$ & 330 & 135 \\
\hline
\end{tabular}


(Phase III-a); and HWT for residential electrification (Phase III-b). So far, about 142,000 people have indirectly (Phase I) or directly (Phases II and III) benefited from the program (Table 1) (MPPEE, 2013a); mostly in southern, northeastern and northwestern territories of Venezuela.

In order to analyze the experience of communities with rural RET, 28 projects were visited between June and September 2016 in the states of Zulia, Falcon, Bolivar and Merida. These projects were selected considering the diversity of the technologies used and the availability of renewable energy sources (RES). In particular, 116 end-user surveys were conducted, as well as interviews with engineers and technicians involved in the program. With this information and some data from the Ministry of Electric Energy, the following aspects of each project were determined: 1) the implemented technology, 2) the number of people who benefited and 3) the installed capacity per inhabitant. The results are summarized in Table 1.

The following sections explain the RES and RET implemented in Venezuela between 2005 and 2013 (Section 2.1), as well as the territory and population scope (Section 2.2). Finally, an analysis of the technology acceptance by end-users and the conditioning factors is provided (Section 2.3). The environmental, technical, socioeconomic and institutional findings obtained from the analysis of the Venezuelan case are used as lessons learned in developing the methodological planning proposal in Section 3.

\subsection{Description of the wind and solar resources}

In this section, the geographical coordinates obtained during project visits are used, as well as satellite wind speed $(\mathrm{m} / \mathrm{s})$ and solar radiation $\left(\mathrm{kWh} / \mathrm{m}^{2}\right.$.day), measures available from the Global Atlas Gallery 3.0 of IRENA (IRENA, 2017c). The wind speed is extrapolated to the hub height of the installed wind turbines $(10 \mathrm{~m})$, based on the wind profile obtained from anemometers at different heights installed by the company Energía Eléctrica de Venezuela (ENELVEN).

It has been found that no project has been implemented in territories with average annual radiation below $4.50 \mathrm{kWh} / \mathrm{m}^{2}$.day, nor have wind turbines been installed at sites with average annual wind speed below $5.70 \mathrm{~m} / \mathrm{s}$. The average values for solar radiation at sites with PV panels (community or SHS) are between 5.50 and $5.63 \mathrm{kWh} / \mathrm{m}^{2}$ day (Fig. 1). In cases where there are high wind speeds and high solar radiation, the AARE has preferably installed HWT (as of 2012). The average value for wind speed in HWT projects is $7.74 \mathrm{~m} / \mathrm{s}$, while for HMG it is $6.84 \mathrm{~m} / \mathrm{s}$ (min: $5.70 \mathrm{~m} / \mathrm{s}$; max: $8.70 \mathrm{~m} / \mathrm{s}$ ).

From the analysis of the RES used in each project, it can be observed how the installed capacity per capita has been progressively higher
(Table 1 and Fig. 1) as the program has progressed. This is due to the use of wind energy, either through HMG (Phase III-a) or HWT (Phase III-b). Indeed, the sites where most recent projects have been installed have better wind conditions, due in part to their increasingly isolated location from large urban centers, free from obstacles and artificial structures, in coastal or Andean territories where houses are dispersed and do not compete with each other for a better use of the wind.

\subsection{Territory and population scope}

In this section the average number of people benefiting from each technology, and the territory extension where the houses are located, are analyzed for the visited projects. This has been done on the basis of surveys and satellite measurements of distances between houses. In the "Sowing Light" program, SHS began to be implemented before HMGs because at first only PV panels were available.

It can be observed that, while the program has progressed and the number of rural houses without electricity has decreased, projects for increasingly dispersed houses have had to be implemented in wider territories using individual supplies. In other words, rural electrification is progressively focused on increasingly dispersed houses where only SHS or HWT systems are possible. In this sense, projects with SHS (Phase II) have covered an average of 14 houses (90 beneficiaries), in an average territory of 220 ha, while projects with HWT (Phase III-b) have covered an average of 15 houses (95 beneficiaries) in territories up to 1075 ha. This contrasts with community electrification. For example, HMGs (Phase III-a) cover areas between 8.5 ha and 30 ha, where an average of 115 people live. In similar territory extensions, community infrastructures were electrified with PV panels (Phase I), indirectly benefiting an average of 345 inhabitants per project.

\subsection{Technology acceptance}

This section focuses on the technology acceptance as the RET are assimilated and adopted favorably by beneficiaries (Bada, 2011). The results from surveys and technical visits show that end-users consider the system very good or excellent, with $66.7 \%$ for SHS, 58.0\% for HMG and $100.0 \%$ for HWT. The favorable acceptance proves that the design estimation of $2 \mathrm{kWh} /$ day of average daily consumption per house (Fundelec, 2015), is satisfactory for users. Additionally, the electric power provided by these projects exceeds the minimum thresholds estimated by the IEA (OECD/EIA, 2010), UNDP (UNDP, 2012) or Practical Action (Tennakoon, 2008). In this regard, the key for technological acceptance is the systems' flexibility and the consistency between their

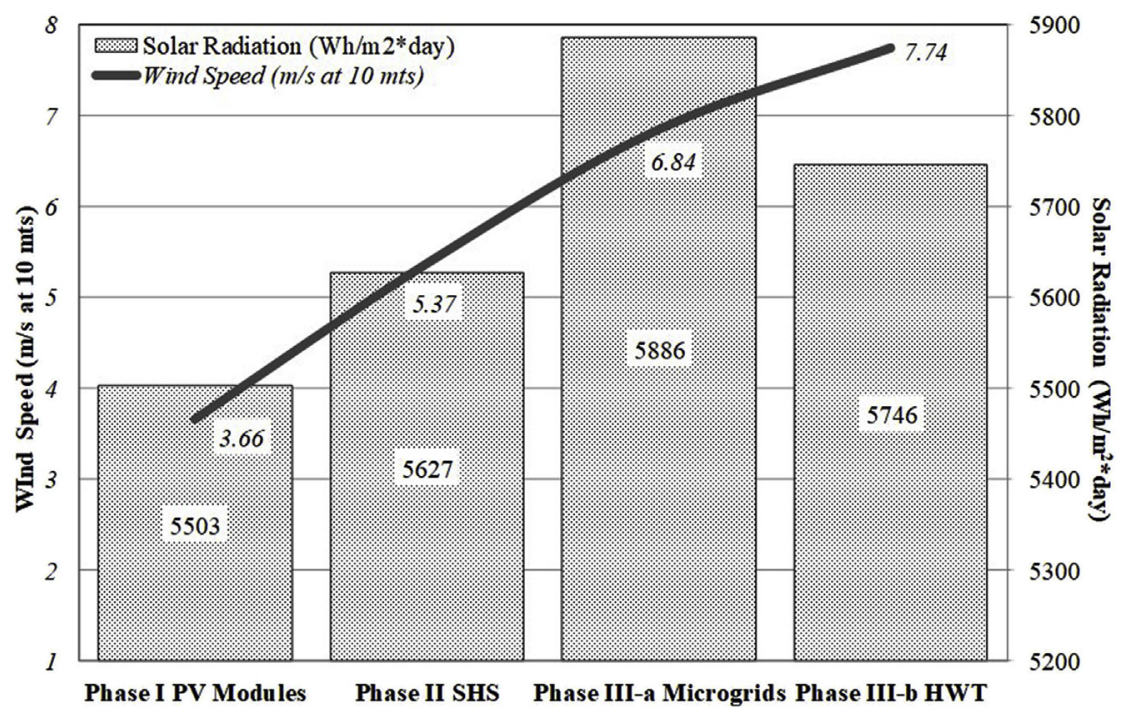

Fig. 1. Average wind and solar resources at the visited projects of "Sowing Light". 


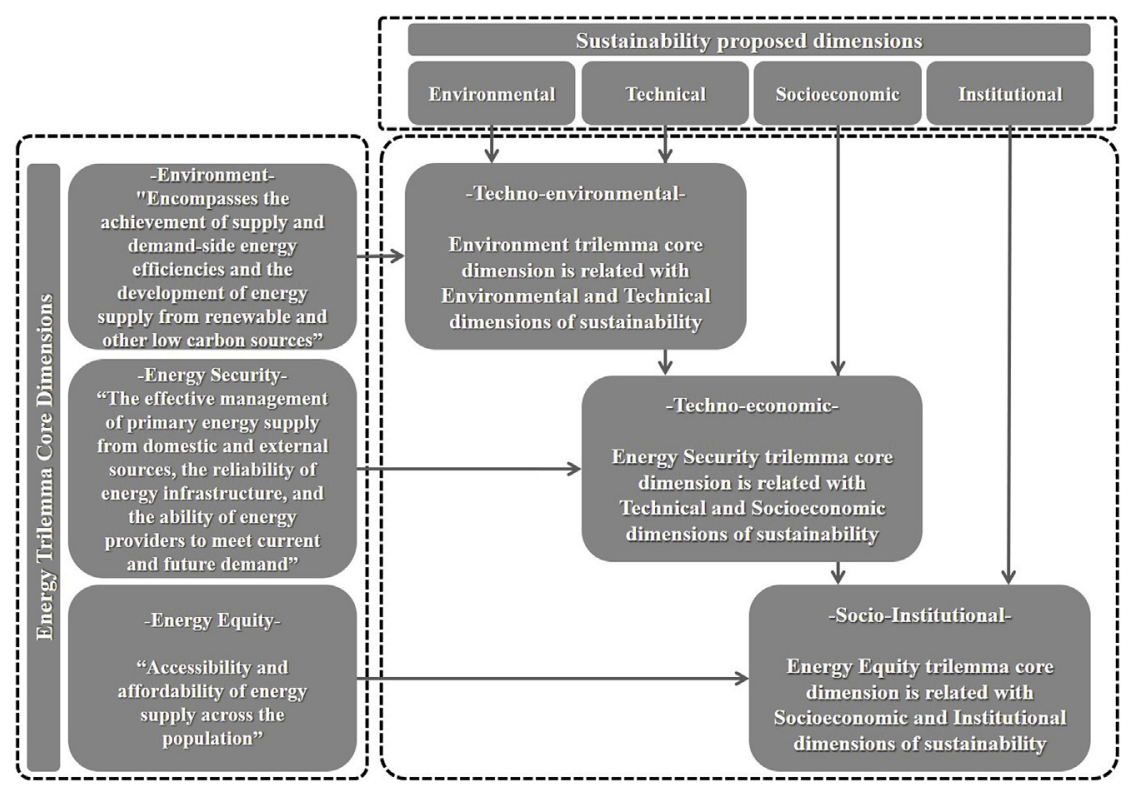

Fig. 2. Categories of objectives for sustainable rural electrification programs.

size and the population's needs (Sovacool, 2013). To do so, the systems' design must be oriented towards energy services, recognizing electrification as the means for accessing food refrigeration, non-polluting lighting, telecommunications, education and health improvements, etc. In short, the technology is more easily accepted by the rural population when it guarantees their requirements and expectations.

It should be noted that the high satisfaction level for HWT is due to the higher installed capacity $(1.5 \mathrm{~kW})$ and their location in high wind speed regions, which results in an energy production much higher than current demand, which could be increased in the medium and long term. The $1.5 \mathrm{~kW}$ HWT installed since 2012 represent a welcome innovation, adopted by beneficiaries even in small villages where HMG also exist. Note that other authors have found similar results in Iran (Hosseinalizadeh et al., 2017) and Greece (Kaldellis et al., 2007), for this technology used on a similar scale. Therefore, even though the participation of HWT in off-grid rural electrification between 2007 and 2016 has been minimal worldwide (IRENA, 2017a), and in particular significantly below SHS, an increase can be expected in the coming years.

Regarding the lower HMG satisfaction, this may indicate that endusers prefer individual systems as long as energy availability is equal to or greater than the energy needs. Thus, the perception of HMG users may be conditioned by the uncertainty about the capacity of such systems to meet the demand growth in the medium and long term. The annual growth rate in demand for rural houses in Venezuela is $2.54 \%$ (Instituto Nacional de Estadística, 2017) which means it will double after 20-25 years. In this regard, in future programs, domestic systems (HWT and/or SHS) may be preferable to HMG, with adjusted designs between generating capacity and expected demand.

\section{Proposed methodology for sustainable rural electrification planning}

This section describes the methodological proposal for sustainable rural electrification planning at regional and/or national level. In this process, the participation and knowledge of the regulatory entity (RE) is required, as a link between rural development institutions: the electricity service company (ESC) and the autonomous authority of rural electrification (AARE) (Haanyika, 2006). The ESC addresses the expansion of generating capacity and the extension of distribution networks to partially electrified villages. The AARE promotes electrification of the rural population through isolated systems, either diesel generators or renewable energy-based technologies (RET). Both initiatives are carried out under the Electrical System Development Plan.

The methodology proposes to address rural electrification planning from the perspective of overcoming the energy trilemma (WEC, 2013), considering different dimensions of sustainability. Thus, the conceptual framework is the set of premises (general and specific) necessary for the development of a program (Trochim and Linton, 1986). Specifically, the general reference is the set of sustainability dimensions (Brundtland, 1987). These were originally defined as (Munasinghe, 2004): social, economic and environmental. Some researchers later suggested up to five dimensions at the local level, in rural electrification projects (Ilskog, 2008). In this paper, four dimensions are proposed for national and/or regional planning: environmental, technical, socioeconomic and institutional. The environmental has to do with the impact that the project has on the local environment and fragile ecosystems preservation. The technical refers to the adequacy and reliability of the installed systems and energy security. The socioeconomic is related to social and economic development as well as community organization, that ease maintenance and security. Finally, the institutional refers to political alignment of decision makers and institutions linked to sustainable rural development with the electrification program. In addition, the particular reference are the three cores of the energy trilemma (environment, energy security and energy equity), as defined by the World Energy Council (WEC, 2013).

The conceptual framework of the planning methodology is outlined in Fig. 2, detailing the four sustainability dimensions (by columns) and the three energy trilemma cores (by rows). As observed, there is consistency since each core (specific reference) is related to two dimensions (general reference), thus defining 3 categories: techno-environmental, techno-economic and socio-institutional. Three objectives are defined for each category, to be pursued in order to undertake national and/or regional rural electrification programs that promote the beneficiaries' sustainable development. Table 2 details these objectives for each category, which are applicable to any rural electrification program addressing the energy trilemma (WEC, 2013) from a sustainability perspective (Munasinghe, 2004).

The methodology has been structured in 4 stages, described in detail in the following sections:

1. Target population definition, considering non-electrified population clusters.

2. Projects' evaluation and prioritization, depending on the program 
Table 2

Proposed objectives for sustainable rural electrification of isolated communities based on the energy trilemma cores and sustainability dimensions.

\begin{tabular}{|c|c|c|}
\hline \multirow{2}{*}{$\begin{array}{l}\text { Category } \\
\text { Techno-environmental }(E+T)\end{array}$} & \multicolumn{2}{|c|}{ Objective } \\
\hline & $\mathrm{O} 1$ & $\begin{array}{l}\text { Provide rural communities located in remote and fragile environment areas with electrification technologies not having an impact on local } \\
\text { ecosystems. }\end{array}$ \\
\hline & $\mathrm{O} 2$ & $\begin{array}{l}\text { Take advantage of renewable energy resources available in communities for electricity generation with minimum pollutant emissions and } \\
\text { high energy efficiency standards. }\end{array}$ \\
\hline & $\mathrm{O} 3$ & Promote rational and efficient use of energy among beneficiaries through technological change. \\
\hline \multirow[t]{3}{*}{ Techno-economic $(\mathrm{T}+\mathrm{SE})$} & $\mathrm{O} 4$ & Provide reliable and adequate electricity supply for the development of new productive activities. \\
\hline & O5 & Satisfy present and future electricity demand of houses and community infrastructures. \\
\hline & O6 & Diversify the energy matrix of the country or region focused by reducing the need for fossil fuel importation. \\
\hline \multirow[t]{3}{*}{ Socio-institutional $(\mathrm{SE}+\mathrm{I})$} & O7 & $\begin{array}{l}\text { Reduce the energy gap between countryside and cities, reducing energy poverty through affordable electricity for the poorest and } \\
\text { geographically isolated communities in the country or region. }\end{array}$ \\
\hline & $\mathrm{O} 8$ & Provide support, via electricity, to improve and develop new community infrastructures for education, health and telecommunications. \\
\hline & 09 & Effectively contribute to the sustainable development of beneficiaries by means of an adequate institutional alignment. \\
\hline
\end{tabular}

objectives.

3. Projects' classification, according to the population cluster and available RES.

4. Projects' portfolio definition, subject to the budget capacity and technological availability.

\subsection{Stage 1: target population definition}

Stage 1 defines the target population of the rural electrification program. To do so, first, the non-electrified population clusters must be distinguished. Specifically, this methodology proposes 6 clusters which have been used in Venezuela (INE, 2014). However, these clusters should be adapted according to the peculiarities of each studied region.

- (P1) non-electrified houses located in electrified urban clusters (pop. $\geq 2,500$ ).

- (P2) non-electrified houses located in electrified rural clusters (pop. $<2,500$ ).

- (P3) non-electrified houses located in non-electrified rural clusters (500 $\leq$ pop. $<2,500)$.

- (P4) non-electrified houses located in non-electrified rural cluster (pop. < 500).

- (P5) dispersed population (less than 3 houses within a $70 \mathrm{~km}$ radius).

- (P6) Non-electrified community infrastructures in non-electrified rural clusters (pop. $<500$ )

Once the population clusters have been defined, the target population of the program can be analyzed. Fig. 3 shows the interactions between stakeholders (RE, ESC and AARE) regarding the Electrical System Development Plan, delimiting the type of programs carried out by each and the population cluster focused. Note that, by their nature, community infrastructures (P6) can be addressed in any type of program. On the other hand, projects dealing with dispersed population (P5) consider groups of houses according to the territorial division (municipality, parish, locality or the smallest division within the territorial organization of the country). The target population will have different treatments regarding the ownership regime for the electrification systems. In this sense, the treatment of (P5), where the systems are individual per house cannot be the same than (P4) and/or (P6) where there is a community interest in the reliability and sustainability of the electrification systems.

In short, the sustainable rural electrification planning methodology mainly focuses on off-grid renewables and microgrids (non-electrified population clusters P4, P5 and/or P6), excluding infrastructures included in the ESC or AARE diesel-based programs. Therefore, the communities included within the target population must be ranked hierarchically, according to the evaluation criteria proposed in the following section.

\subsection{Stage 2: projects evaluation and prioritization}

Stage 2 evaluates and prioritizes projects within the target population. Electrification programs must consider, as a priority, those communities whose electrification most directly impacts on the achievement of objectives (Table 2) (World Bank, 2008). Toto assess the objectives, criteria re proposed considering elements derived from the analysis and lessons learned from the "Sowing Light" program (Section 2). Thus, a set of project evaluation criteria are defined, as well as the way each project is evaluated regarding each criterion and the criteria weights. Criteria evaluations have a range of 3 or 4 values $(0,1,3$ or 5$)$, depending on how each project's characteristics meet the purpose of the criterion. The weight of each criterion represents its relevance regarding the others, and is calculated according to the number of program objectives focused (Table 2). For the sake of clarity, the weights are normalized and adjusted at 5\% intervals. The evaluation range $(0-5)$ and $5 \%$ intervals are based on practices of the Venezuelan Ministry of Electric Energy (MPPEE, 2013b).

- Resources availability: solar energy is the most abundant and uniformly distributed renewable resource in the world, while the wind is usable in a much more restricted territory. Solar energy is considered usable for electricity generation from an average daily radiation of between 3 and $6 \mathrm{kWh} / \mathrm{m}^{2}$. For wind energy, works carried out in Iran (Hosseinalizadeh et al., 2017), Greece (Kaldellis et al., 2007) and Venezuela (Fundelec, 2012), conclude that an average wind speed between 5 and $7 \mathrm{~m} / \mathrm{s}$, at hub height, is adequate for domestic or community rural electrification. As a feasibility criterion, minimum daily average thresholds of $5 \mathrm{kWh} / \mathrm{m}^{2}$ for the solar resource and $5 \mathrm{~m} / \mathrm{s}$ for the wind resource are suggested. Therefore, three evaluation scales are established: (1) PV, solar $\geq 5 \mathrm{kWh} / \mathrm{m}^{2}$ and wind $<5 \mathrm{~m} / \mathrm{s}$; (3) Wind, solar $<5 \mathrm{kWh} / \mathrm{m}^{2}$ and wind $\geq 5 \mathrm{~m} /$ $\mathrm{s}$; and (5) Wind-PV, solar $\geq 5 \mathrm{kWh} / \mathrm{m}^{2}$ and wind $\geq 5 \mathrm{~m} / \mathrm{s}$. Only through an adequate evaluation of resources can the energy security of the community and electrified homes be guaranteed. This criterion is related to 4 objectives (Table 2): O2, O4, $\mathrm{O} 5$ and $\mathrm{O6}$. Therefore, its weight is $25 \%$.

- Community organization: priority is given to rural settlements where some social organization exists. In case of community councils or neighborhood assemblies, among others, a value of 1 is considered. If there is a productive association (fishermen, farmers, artisans, etc.) a value of 3 is considered. Finally, if there are both organizations, a value of 5 is considered. In the process of installation and maintenance of the systems, an adequate community organization for participation has a key importance on the reduction of costs. This criterion is intended to ensure the necessary maintenance activities to be effectively carried out by an organized community. It is assumed that the government transfers maintenance competencies to community organizations. This criterion is related to 3 objectives (Table 2): O3, 04 and O9. Therefore, its weight is $20 \%$. The 


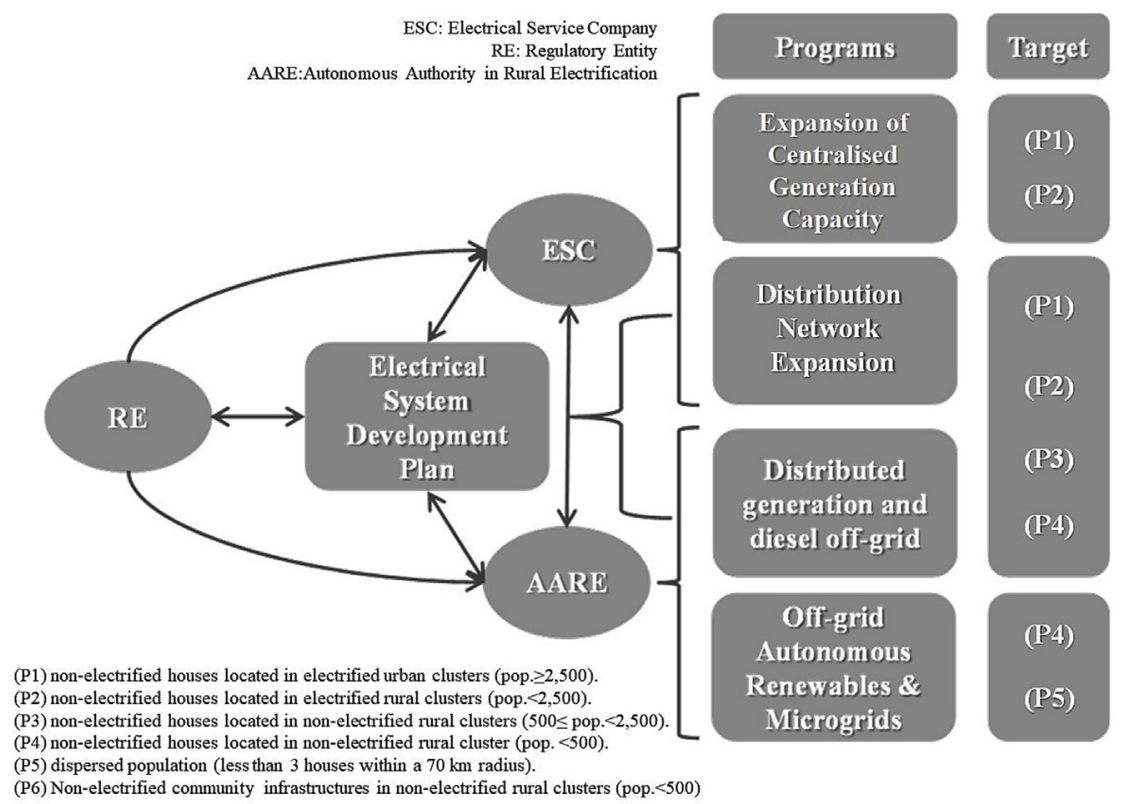

Fig. 3. Stakeholders, electrification programs and corresponding target population.

organization of the community guarantees the ownership transfer of electrification systems to a group of people recognized by all members of the community. This transfer can be direct, without intermediaries, or indirect through the return of an initial loan, granted by the government or a private entity. Individual systems will be supported by government institutions to form user cooperatives; as micro-enterprises or local companies could not be applicable to individual groups of costumers. Indeed an effective community organization can guarantee the security of the facilities, for example, being able to organize neighborhood security brigades.

- Distance to next electrified town: priority is given to rural settlements farther away from electrified towns. Therefore, three evaluation scales are established: (1) distance $<10 \mathrm{~km}$; (3) $10 \mathrm{~km} \leq$ distance $<70 \mathrm{~km}$; and (5) distance $\geq 70 \mathrm{~km}$. This criterion is closely related to the energy policy of the government that implements the plan. In this regard, these ranges have been considered based on the experience in Venezuela, but others could be assumed according to the local political context. This criterion has been included in order to promote energy equity trough rural electrification programs. This criterion is related to 2 objectives (Table 2): $\mathrm{O} 1$ and 07 . Therefore, its weight is $10 \%$.

- Number of houses: priority is given to non-electrified rural settlements having a greater number of inhabitants. Therefore, three evaluation scales are established: (1) number of houses $<20$; (3) $20 \leq$ number of houses $<40$; and (5) number of houses $\geq 40$. This criterion is related to the stages that the energy policy of the government had defined for the electrification program. In this regard, these ranges of houses could be assumed according to the local demographic and political context. This criterion has been included in order to promote energy equity through rural electrification programs. This criterion is related to 2 objectives (Table 2): $\mathrm{O} 1$ and O7. Therefore, its weight is $10 \%$.

- Region REI (\%): priority is given to rural settlements located in regions where the Rural Electrification Index (REI, \%) is lower than the average of the target population. Therefore, three evaluation scales are established: (1) REI $>98 \%$; (3) target population average $<$ REI $\leq 98 \%$; and (5) REI $\leq$ target population average. This criterion assumes that the government that promotes the plan is politically committed to achieve the better possible performance on rural electrification indices, particularly in less electrified regions. This criterion has been included in order to promote energy equity trough rural electrification programs. This criterion is related to 2 objectives (Table 2): $\mathrm{O} 1$ and O7. Therefore, its weight is $10 \%$.

- High carbon energy use: priority is given to rural settlements where current energy use pollutes most. Therefore, four evaluation scales are established: (0) no polluting use; (1) community diesel; (3) individual diesel; and (5) kerosene lamps and firewood. This criterion assumes that the government that promotes the plan is politically committed to achieve low carbon emissions. This criterion is related to 2 objectives (Table 2): 03 and O6. Therefore, its weight is $10 \%$.

- Fragile ecosystem: Rural and/or indigenous settlements located within fragile ecosystems, such as national parks, are prioritized to avoid electrification through fossil fuel systems. Therefore, four evaluation scales are established according to the location: (0) not national park nor indigenous community; (1) indigenous community; (3) national park; and (5) indigenous community within a national park. This criterion assumes that the government that promotes the plan is politically committed with the presentation of fragile ecosystems. This criterion is related to 2 objectives (Table 2): $\mathrm{O} 1$ and $\mathrm{O} 2$. Therefore, its weight is $10 \%$.

- Education and health non-electrified infrastructures: priority is given to rural settlements where there is an education and/or health infrastructure without electricity. Therefore, three evaluation scales are established: (0) no education and health infrastructures; (3) one non-electrified infrastructure (education or health); (5) both education and health infrastructures non-electrified. This criterion assumes that the government that promotes the plan is politically committed to improve health and education services in rural areas. This criterion is related to objective 08 (Table 2), so its weight is $5 \%$.

Table 3 shows the hierarchical evaluation matrix obtained with the information described above. Specifically, for each evaluation criterion, the weight, the evaluation definitions and the corresponding value are shown. This matrix is used for the prioritization of communities within the target population, ranking from highest to lowest the weighted sum of the evaluations for all criteria. This prioritization is used in the next stage for project classification.

\subsection{Stage 3: project classification}

Once the hierarchical evaluation matrix is obtained and the target 
Table 3

Hierarchical evaluation matrix for communities included in the target population.

\begin{tabular}{|c|c|c|c|}
\hline Evaluation criteria & Weight & Evaluation definition & Value \\
\hline \multirow[t]{3}{*}{ Resources availability } & \multirow[t]{3}{*}{$25 \%$} & PV & 1 \\
\hline & & Wind & 3 \\
\hline & & Wind-PV & 5 \\
\hline \multirow[t]{3}{*}{ Community organization } & \multirow[t]{3}{*}{$20 \%$} & Communal & 1 \\
\hline & & Productive & 3 \\
\hline & & Communal \& Productive & 5 \\
\hline \multirow[t]{3}{*}{ Distance to next electrified town } & \multirow[t]{3}{*}{$10 \%$} & distance $<10 \mathrm{~km}$ & 1 \\
\hline & & $\begin{array}{l}10 \mathrm{~km} \leq \text { distance } \\
<70 \mathrm{~km}\end{array}$ & 3 \\
\hline & & distance $\geq 70 \mathrm{~km}$ & 5 \\
\hline \multirow[t]{3}{*}{ Number of houses } & \multirow[t]{3}{*}{$10 \%$} & no. houses $<20$ & 1 \\
\hline & & $20 \leq$ no. houses $<40$ & 3 \\
\hline & & no. houses $\geq 40$ & 5 \\
\hline \multirow[t]{3}{*}{ Region REI (\%) } & \multirow[t]{3}{*}{$10 \%$} & REI $>98 \%$ & 1 \\
\hline & & $\begin{array}{l}98 \% \geq \mathrm{REI}>\mathrm{TP} \\
\text { average }\end{array}$ & 3 \\
\hline & & $\mathrm{REI} \leq \mathrm{TP}$ average & 5 \\
\hline \multirow[t]{4}{*}{ High carbon energy use } & \multirow[t]{4}{*}{$10 \%$} & No polluting use & 0 \\
\hline & & Community diesel & 1 \\
\hline & & Individual diesel & 3 \\
\hline & & $\begin{array}{l}\text { Kerosene lamps \& } \\
\text { firewood }\end{array}$ & 5 \\
\hline \multirow[t]{4}{*}{ Fragile ecosystem } & \multirow[t]{4}{*}{$10 \%$} & No IC and no NP & 0 \\
\hline & & $\begin{array}{l}\text { Indigenous Community } \\
\text { (IC) }\end{array}$ & 1 \\
\hline & & National Park (NP) & 3 \\
\hline & & NP and IC & 5 \\
\hline \multirow{3}{*}{$\begin{array}{l}\text { Education and health non- } \\
\text { electrified infrastructures }\end{array}$} & \multirow[t]{3}{*}{$5 \%$} & No E \& H infrastructures & 0 \\
\hline & & $\begin{array}{l}\text { One non-electrified (E or } \\
\mathrm{H})\end{array}$ & 3 \\
\hline & & $\begin{array}{l}\text { Both non-electrified (E \& } \\
\text { H) }\end{array}$ & 5 \\
\hline
\end{tabular}

population is chosen, the communities are classified according to the type of project to be implemented, defining the electricity distribution and generation technologies. This classification enables project standardization for estimating costs, which is necessary for defining the project portfolio.

The electricity distribution technologies to be implemented are determined by the dispersion of population, defining the use of individual systems or microgrids. In this sense, dispersed population (P5) and community infrastructures (P6) are proposed for electrification by means of individual solar systems (SHS or PV for community infrastructures) and/or wind (HWT or WT for community infrastructures). For non-electrified houses in non-electrified clusters (P4) three alternatives are proposed: 1) SHS or HWT; 2) hybrid or solar microgrids; or 3) hybrid or solar microgrids, with SHS and/or HWT for scattered points. In addition, the use of individual systems is proposed in communities with 20 or fewer houses, even in small territories, given the limitations for microgrids (Section 2). Thus, such communities previously grouped as P4 are considered as P5 for the project classification.

Next, the electricity generation technologies to be used are defined, based on the availability of RES in each community. From the experiences and lessons learned in Venezuela (Section 2), it is proposed that where both wind and solar resources abound, the implementation of hybrid or wind technologies should be prioritized before solar PV.

\subsection{Stage 4: projects portfolio definition}

The projects portfolio is a list of projects classified according to their type (Section 3.3) and ordered according to their priority (Section 3.2). Specifically, the projects portfolio is first divided according to the target population (P4, P5 or P6). Within each cluster, the projects are subdivided according to the availability of RES. Thus, the projects are distinguished according to the technology to be used: solar (PV microgrid, SHS or PV for community infrastructures), wind (HWT or WT for community infrastructures) or both (HMG). Hence, projects are executed in hierarchical order, depending on the country availability for RET systems and/or financial resources for RET importation and works execution.

Fig. 4 shows the general structure for the proposed methodology. The starting point is the objective derived from the solution of the energy trilemma by means of the four proposed sustainability dimensions. Next, the target population and their clusters are defined (Stage 1). Projects are then prioritized according to the hierarchical evaluation matrix (Stage 2). Thus, projects are divided with regard to house dispersion and energy source availability (Stage 3 ). Finally, the projects portfolio is defined considering the country availability for accessing technologies (Stage 4).

Finally, in order to implement the project portfolio, it only remains necessary to make on-site visits to perform the latest technical and/or social adaptations of the planned projects. For example, in terms of technical constraints, there may be restrictions in the layout of houses, physical conditions of the community or environmental aspects that may affect the equipment to be used. In turn, social restrictions are deduced from the effective communication between the AARE and endusers. For example, the need and conditions established by community leaders or the real capacity of communities to be involved with the installation, operation and maintenance of equipment must be considered. Nevertheless, considering the technical and social constraints of each community from on-site visits is fundamental for the technology acceptance of rural electrification systems based on renewable energy (Bazilian et al., 2012) (Urmee and Md, 2016).

\section{Case study: electrification of isolated communities in Venezuela}

In Venezuela, $0.3 \%$ of the population lacks electricity (MPPEE, 2013b). This population is distributed in houses located in 2,525 rural villages that, given their emplacement, have not been reached by the national electricity network nor other electricity access strategies executed by the ESC or the AARE (Instituto Nacional de Estadística, 2017). These communities are mostly located in indigenous and/or border territories. In this section, the methodology proposed for sustainable rural electrification planning is applied to these houses. Consequently, the methodological proposal is explained and a projects portfolio for Venezuela is obtained in order to progress with universal electricity access in the country. The following sections describe each stage of the planning methodology.

\subsection{Stage 1: target population definition}

Most non-electrified rural settlements in Venezuela are concentrated in the most isolated territories of the states of Zulia, Falcon, Bolivar, Amazonas, Apure and Delta Amacuro (Instituto Nacional de Estadistica, 2013). There are 2,269 non-electrified rural villages in these states, $89.8 \%$ of the national total $(2,525)$. Specifically, it has been found that $70.48 \%(1,599)$ of these communities correspond to the P4 population cluster, while $25.91 \%$ (588) belong to P5 and $3.61 \%$ (82) to P6. Consequently, this target population is considered for this case study.

\subsection{Stage 2: projects evaluation and prioritization}

The 2,269 communities defined as the target population of the program are hierarchically ordered according to the evaluation matrix described in Table 3. Note that the main determining factors in the hierarchy are the availability of the wind and solar energy resources throughout the territory and the community organization, which in Venezuela corresponds to officially constituted communal councils. Between both factors, they add up to $45 \%$ of the total hierarchical weighting and determine to a large extent the order of prioritization. 


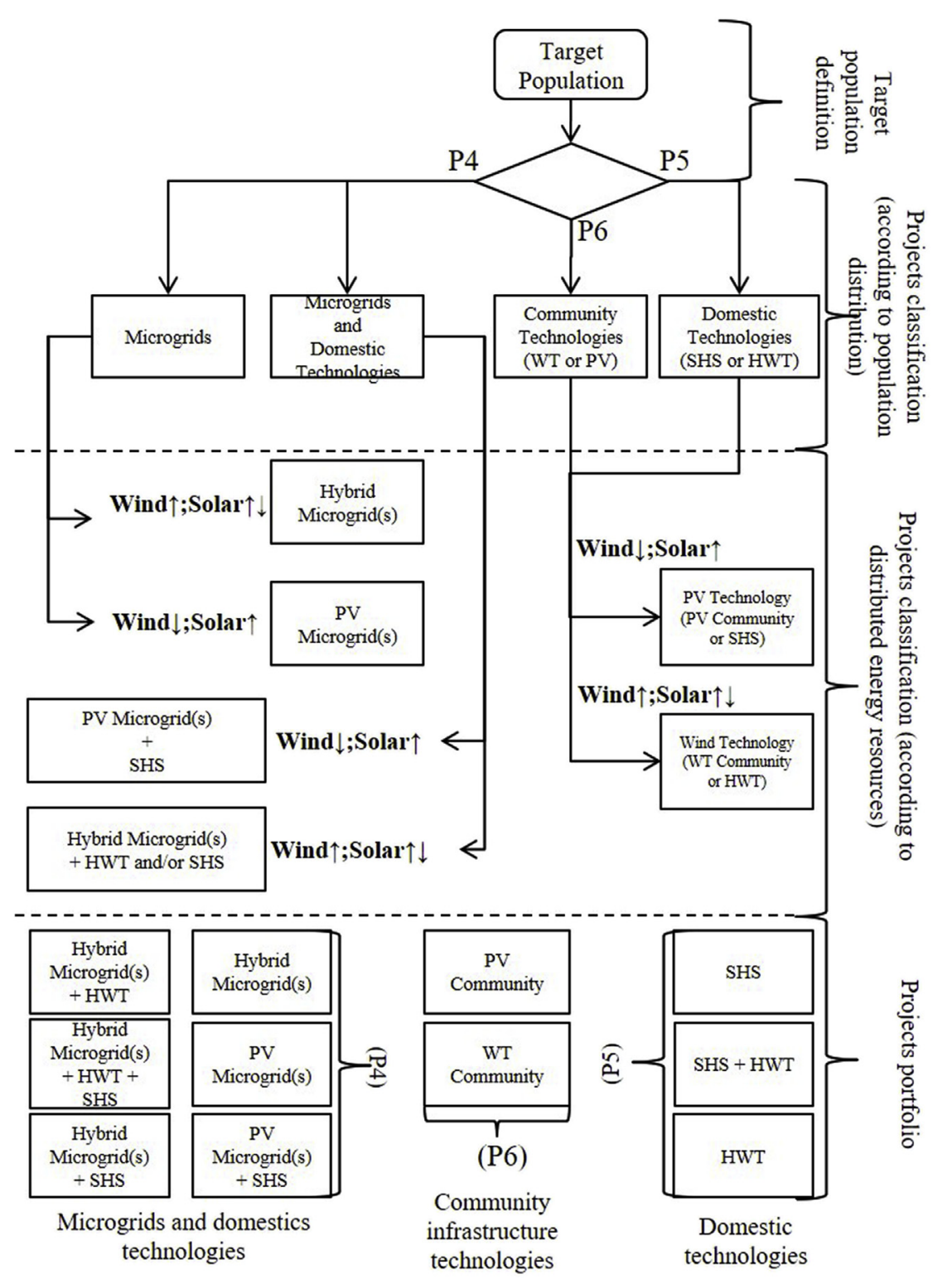

Fig. 4. Proposed design stages for sustainable rural electrification planning.

\subsection{Stage 3: projects classification}

In this stage, the villages are classified according to house dispersion and RES availability, to define the electricity distribution and generation technologies, respectively.

Regarding the dispersion of the target population, Fig. 5 shows the percentage distribution of houses in non-electrified communities for the 6 Venezuelan states examined, based on data from the National Statistics Institute of Venezuela (Instituto Nacional de Estadística, 2017). It can be seen that $25.91 \%$ of the target population (588 communities) consists of 3 or fewer houses, corresponding to cluster P5. Among the remaining $74.09 \%$, there are 1,599 communities $(70.48 \%)$ that only consist of houses (P4) and 82 communities (3.61\%) which also have community infrastructures (P4 and P6). However, within P4, there are 1,342 communities $(59.15 \%)$ with between 4 and 20 houses, which should be classified as P5 for electrification using individual systems (SHS or HWT) instead of microgrids, as drawn from the lessons learned from the "Sowing Light" program (Section 2). In short, the following electricity distribution technologies are proposed (Fig. 4): 339 P4 communities with microgrids and, if necessary, domestic systems; 1,930 P5 communities with domestic systems; and 82 P6 communities with community infrastructure systems.

Regarding the RES availability, Fig. 6 shows the distribution of the target population throughout the 6 states studied here. In addition, the average distribution of the wind and solar energy resources is also illustrated. It can be observed that the communities from Zulia and Falcon have favorable conditions for wind and/or solar projects, according to the resource criteria (Table 3) and the methodological scheme (Fig. 4). In contrast, for communities located in the other states, the conditions are only favorable for solar energy. Finally, note that Fig. 6 shows higher community dispersion in Amazonas and Bolivar, while the concentration is slightly higher in Apure and Delta Amacuro, and significantly higher in Falcon and Zulia. Thus, it can be expected that in Amazonas and Bolivar the process will have higher logistics costs than in states where communities are closer to each other.

\subsection{Stage 4: projects portfolio definition}

With the information described, projects can be developed (Table 4), taking into account projects prioritization (Stage 2) and classifications according to the population clusters and RES (Stage 3). Therefore, three phases are proposed for the program development. In 


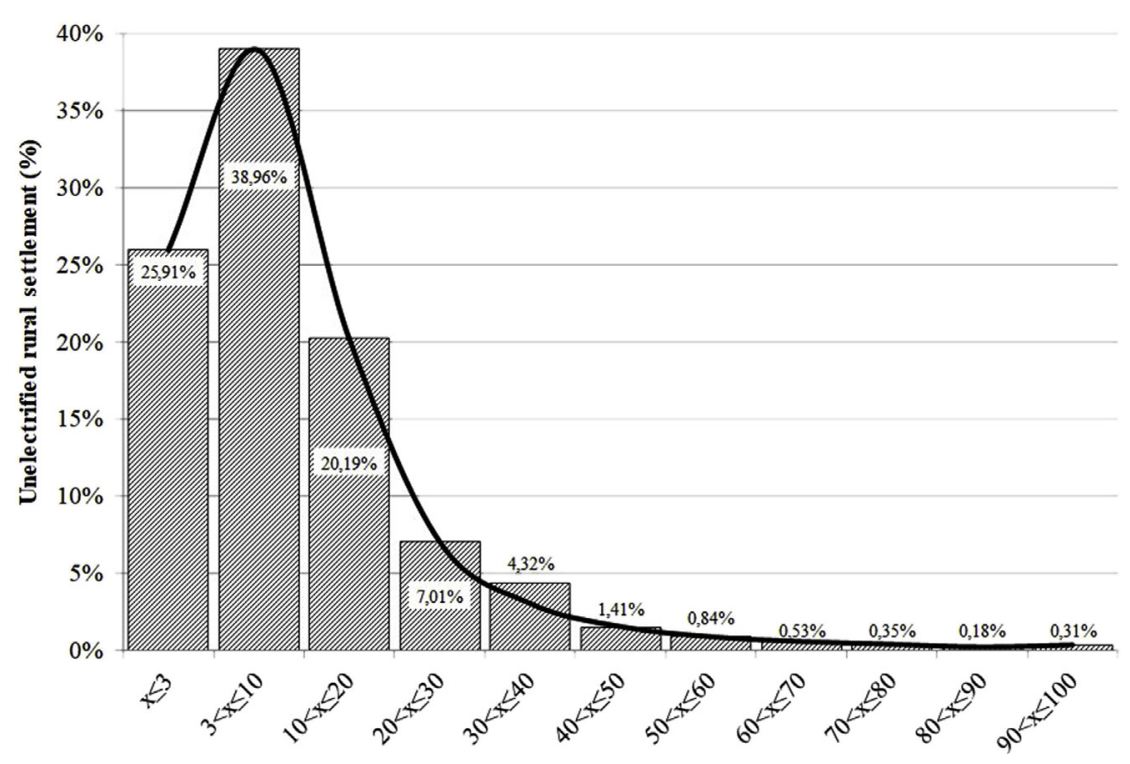

Fig. 5. Number of houses in non-electrified rural settlements of the Venezuelan target population.

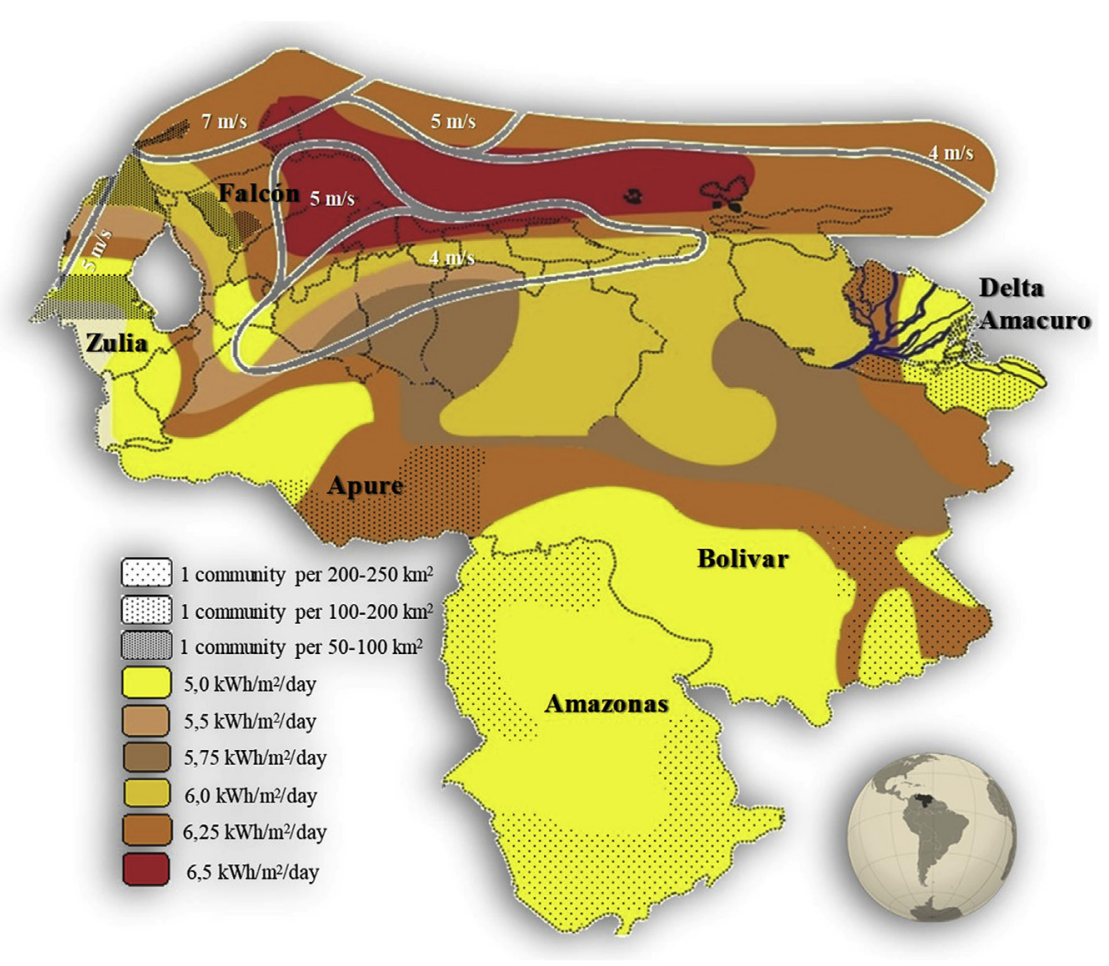

Fig. 6. Target population distribution and wind-solar energy resources throughout Venezuela.

Table 4

Proposed projects portfolio to achieve universal electricity access for the target population and planned implementation phases.

\begin{tabular}{|c|c|c|c|c|c|c|}
\hline Phase & Target population & Energy resources & Technologies implemented & Communities & Target infrastructures & Benefited houses \\
\hline \multirow[t]{2}{*}{ I } & \multirow[t]{2}{*}{$\mathrm{P}^{\mathrm{a}}$} & Wind $\uparrow ;$ Solar $\downarrow$ & WT for community infrastructures & 20 & \multirow[t]{2}{*}{ Schools and Health Centers } & 780 \\
\hline & & Wind $\downarrow$; Solar $\uparrow$ & PV for community infrastructures & 62 & & 1,674 \\
\hline \multirow[t]{3}{*}{ II } & \multirow[t]{3}{*}{ P4 } & Wind $\uparrow ;$ Solar $\uparrow \downarrow$ & HMG & 53 & \multirow[t]{5}{*}{ Houses } & 1,575 \\
\hline & & Wind $\downarrow$; Solar $\uparrow$ & PV microgrids & 156 & & 4,629 \\
\hline & & Wind $\downarrow$; Solar $\uparrow$ & $\mathrm{PV}$ microgrids $+\mathrm{SHS}$ & 89 & & 4,386 \\
\hline \multirow[t]{2}{*}{ III } & \multirow[t]{2}{*}{ P5 } & Wind $\uparrow ;$ Solar $\downarrow$ & HWT & 220 & & 657 \\
\hline & & Wind $\downarrow$; Solar $\uparrow$ & SHS & 1710 & & 5,872 \\
\hline
\end{tabular}

${ }^{\text {a }}$ Benefited houses of these projects are also considered for phase II (population category P4). 
Phase I (Table 4), the 82 communities with infrastructures (schools and health centers) without electricity (P6) will be prioritized. Specifically, 20 of these communities are located in Zulia and Falcon with good wind resources, so wind turbines will be used; while PV panels will be utilized for the remaining 62 . This will quickly benefit 2,454 houses, at a limited cost.

In Phase II (Table 4), the electrification of rural settlements with more than 20 houses (P4) using HMG in northwestern regions (Zulia and Falcon) and PV microgrids in southern (Apure, Amazonas and Bolivar) and eastern (Delta Amacuro) regions, will be carried out. The microgrids are designed to supply electricity to up to 30 or 40 houses, using different configurations of wind turbines and PV panels. In case there are dispersed houses within those communities, for which microgrid extension is not feasible, HWT is preferable for Zulia and Falcon, and SHS in the other states. This will provide electricity access to 12,732 houses.

Finally, in Phase III (Table 4), electrification of the dispersed population (P5) will be undertaken, at a significantly higher cost per beneficiary due to the dispersion of houses. In this case, domestic systems will be used, either HWT in Zulia and Falcon, or mostly SHS in Apure, Amazonas, Bolivar and Delta Amacuro. This will reach the remaining 6,529 homes in the 6 states studied, achieving universal access in these regions.

Finally, the AARE must carry out technical visits to each community and verify the on-site conditions for the program development. Therefore, the initially conceived RET and design configurations may change according to the specific characteristics observed. For example, in Zulia and Falcon, where mostly HWT are proposed for isolated houses, some locations sheltered from the wind may be identified for implementing SHS. In addition, Venezuela has a state-owned company manufacturing wind turbines and solar panels (De Pablos, 2014). Consequently, the projects portfolio will be influenced by the availability of such equipment, but not the financial availability for their importation. In this regard, the manufacturer has an annual production capacity of 200 wind turbines with nominal power of $1.5,3$ and $6 \mathrm{~kW}$, as well as 20,800 PV panels of $195 \mathrm{Wp}$. Thus, the projects portfolio may be adjusted to such equipment. In particular, Table 5 shows the Venezuelan wind turbines and PV panels needed for the projects considered for the target population. As observed, for the development of the proposed rural electrification program, 1,159 wind turbines of $1.5 \mathrm{~kW}$, 93 of $3 \mathrm{~kW}$ and 135 of $6 \mathrm{~kW}$ are required; as well as 49,669 PV panels of $195 \mathrm{Wp}$.

\section{Conclusion and policy implications}

Most of the rural electrification programs implemented world-wide have been planned considering objectives based on a limited set of sustainability dimensions, thereby conditioning their medium and longterm development. Therefore, this paper proposes a methodology to develop rural electrification plans at regional and/or national level, which allows the three energy trilemma core to be overcome by means of four sustainability dimensions. Each core is related to two dimensions, distinguishing three categories (techno-environmental, technoeconomic and socio-institutional) for which planning objectives are defined to achieve the sustainable development of beneficiaries.

The proposed methodology is a tool for RET-based national energy policy for rural electrification. In particular, the execution of the methodology generates a projects portfolio within a national frame, according to the energy policy. More specifically, the methodology can be useful to estimate the needs for investment at a national level and, therefore, to adequately plan a schedule for projects' execution from a centralized perspective. Considering the incomes dependency of developing countries on raw materials exportations, a national wide planning guarantees sustainability in the medium and long term over a wide scope. In this sense, all the regional plans, must be framed into the national rural electrification program that can be defined through this methodology.

For the preparation of the methodological proposal, the lessons learned from the "Sowing Light" program in Venezuela, developed between 2005 and 2013, were considered. This program benefited 142,000 people using PV panels and/or wind turbines, as individual systems or microgrids. Hence, the methodology proposes 9 objectives to plan sustainable rural electrification programs and includes 4 stages. First of all, the target population of the program is identified. Secondly, the target population is evaluated by means of some criteria that measure the weighted impact on the 9 objectives, thus defining projects prioritization. In third place, the projects are classified according to house dispersion and energy resource availability, in order to define the electricity generation and distribution technologies to be used. Finally, the projects portfolio is established, determining the execution order of projects, depending on the country availability of renewable energy technologies and/or financial resources for their importation.

The proposed methodology has been applied to the 6 Venezuelan states where most of the houses without electricity are concentrated, in order to progress to universal access. In this sense, 3 phases for projects implementation are proposed: (I) community infrastructures through community wind or solar systems; (II) rural settlements larger than 20 houses, using solar or hybrid microgrids and, in some cases, solar or wind domestic systems; and (III) smaller settlements with domestic wind or solar systems. Thus, 2,269 communities (19,261 houses) are expected to benefit, using wind turbines and PV panels manufactured in Venezuela.

The planning methodology is applicable in any other developing country in Latin America, Africa or Asia. It is important to bear in mind that the sustainability of rural electrification programs is based on the fulfillment of the 9 proposed objectives and the hierarchy of beneficiary communities, where the long-term commitment of institutional stakeholders (AARE, ESC and RE) is fundamental. This planning perspective is beneficial, considering the need to expand electricity access in large territories with increasingly dispersed houses, which makes renewable energy-based technologies decisive for accomplishing universal access by 2030 .

Table 5

Technology requirements for the proposed rural electrification plan in Venezuela.

\begin{tabular}{|c|c|c|c|}
\hline Projects & Systems Quantity & Equipment & RET Quantity \\
\hline PV for community infrastructure & 124 & PV Panel 195 Wp & 744 \\
\hline WT for community infrastructure & 40 & WT $3 \mathrm{~kW}$ & 40 \\
\hline \multirow[t]{3}{*}{ HMG (up to 30 houses) } & 53 & PV Panel 195 Wp & 2,279 \\
\hline & & WT $3 \mathrm{~kW}$ & 53 \\
\hline & & WT $6 \mathrm{~kW}$ & 53 \\
\hline \multirow[t]{2}{*}{ HMG (up to 40 houses) } & 41 & PV Panel 195 Wp & 2,255 \\
\hline & & WT $6 \mathrm{~kW}$ & 82 \\
\hline PV microgrid (up to 30 houses) & 156 & PV Panel 195 Wp & 13,884 \\
\hline PV microgrid (up to 40 houses) & 89 & PV Panel 195 Wp & 10,413 \\
\hline HWT & 1,159 & WT $1,5 \mathrm{~kW}$ & 1,159 \\
\hline SHS & 6,698 & PV Panel 195 Wp & 20,094 \\
\hline
\end{tabular}




\section{Acknowledgments}

This research was funded by the Spanish Ministry of Science and Innovation (project ENE 2015-67253-R) and the Center for Cooperation Development (CCD) of the Universitat Politècnica de Catalunya BarcelonaTech (UPC). It has been made possible thanks to the collaboration and support of engineers and technicians of Fundelec, PDVSA and Communal Councils of the 28 visited communities.

\section{References}

ADB, 2017. SEforALL Africa Hub. Abidjan.

Altomonte, H., 2017. Las energías renovables no convencionales en la matriz de generación eléctrica. (Santiago).

Bada, H.A., 2011. Managing the diffusion and adoption of renewable energy technologies in Nigeria. World Renew. Energy Congr. 2642-2649. https://doi.org/10.3384/ ecp110572642.

Banal-Estañol, A., Calzada, J., Jordana, J., 2017. How to achieve full electrification: lessons from Latin America. Energy Policy 108, 55-69. https://doi.org/10.1016/j. enpol.2017.05.036.

Bazilian, M., Nussbaumer, P., Eibs-Singer, C., Brew-Hammond, A., Modi, V., Sovacool, B., Ramana, V., Aqrawi, P.K., 2012. Improving access to modern energy services: insights from case studies. Electr. J. 25, 93-114. https://doi.org/10.1016/j.tej.2012. 01.007 .

BBC, 2008. Bolivia, libre de analfabetismo. BBC Mundo. http://news.bbc.co.uk/hi/ spanish/business/newsid_7793000/7793177.stm, Accessed date: 8 March 2017.

Bhatia, M., Angelou, N., 2015. Beyond Connections Energy Access Redefined. Technical Report 008/15.

Brundtland, G.H., 1987. Our common future: report of the world commission on environment and development. Med. Conflict Surviv. 4, 300. https://doi.org/10.1080/ 07488008808408783 .

Büyüközkan, G., Karabulut, Y., 2017. Energy project performance evaluation with sustainability perspective. Energy 119, 549-560. https://doi.org/10.1016/j.energy. 2016.12.087.

CELAC, 2018. Brasil: Programa Luz para Todos. Plataforma Segur. Aliment. y Nutr. URL. http://plataformacelac.org/programa/1006, Accessed date: 19 April 2018.

Chaurey, A., Kandpal, T.C., 2010. Assessment and evaluation of PV based decentralized rural electrification: an overview. Renew. Sustain. Energy Rev. 14, 2266-2278. https://doi.org/10.1016/j.rser.2010.04.005.

De Pablos, K., 2014. Solar and wind electricity sources. Alternative, clean and renewable energy. Orinoco Magna Reserv. 21-24.

Doll, C.N.H., Pachauri, S., 2010. Estimating rural populations without access to electricity in developing countries through night-time light satellite imagery. Energy Policy 38, 5661-5670. https://doi.org/10.1016/j.enpol.2010.05.014.

Falcón-Roque, E.J., Marcos Martín, F., Pascual Castaño, C., Domínguez-Dafauce, L.C., Bastante Flores, F.J., 2017. Energy planning model with renewable energy using optimization multicriteria techniques for isolated rural communities: Cajamarca province, Peru. J. Renew. Sustain. Energy 9. https://doi.org/10.1063/1.4989574.

Fundelec, 2015. Reseña Histórica: Fundelec. [WWW Document]. URL. http://www. fundelec.gob.ve/?page_id = 310, Accessed date: 1 October 2017

Fundelec, 2012. Sembrando Luz: Promoviendo las Energías Renovables en Zonas Aisladas, Indígenas y Fronterizas del país. pp. 32.

Haanyika, C.M., 2006. Rural electrification policy and institutional linkages. Energy Policy 34, 2977-2993. https://doi.org/10.1016/j.enpol.2005.05.008.

Hosseinalizadeh, R., Rafiei, E. sadat, Alavijeh, A.S., Ghaderi, S.F., 2017. Economic analysis of small wind turbines in residential energy sector in Iran. Sustain. Energy Technol. Assessments 20, 58-71. https://doi.org/10.1016/j.seta.2017.02.018.

IEA, 2014. Africa Energy Outlook: A Focus on Prospects in Sub-Saharan Africa.

Ilskog, E., 2008. Rural Electrification Sustainability Indicators:-Manual for Field Workers.

INE, 2014. XIV Censo Poblacional de Población y Vivienda. Resultados por Entidad Federal y Municipio del Estado Bolívar. Caracas.

Instituto Nacional de Estadistica, 2013. Síntesis Estadística. Síntesis Estadística. http:// www.ine.gov.ve/index.php? option $=$ com_content\&view $=$ category\&layout $=$ blog\& id $=116 \&$ Itemid $=10$, Accessed date: 1 October 2017.

Instituto Nacional de Estadística, 2017. Censo 2011 Redatam. [WWW Document]. URL. http://www.redatam.ine.gob.ve/Censo2011/index.html, Accessed date: 24 March 2017.

IRENA, 2017a. Renewable Capacity Statistics 2016. (Abu Dhabi).

IRENA, 2017b. 2016 a Record Year for Renewables, Latest IRENA Data Reveals. Renew. Energy Capacit. Stat. 2017. http://www.irena.org/News/Description.aspx?NType = A\&mnu $=$ cat\&PriMenuID $=16 \&$ CatID $=84 \&$ News $I D=1486$, Accessed date: 26 April 2017.

IRENA, 2017c. Global Atlas Gallery 3.0. https://irena.masdar.ac.ae/gallery/\#gallery, Accessed date: 19 June 2017.

Jebaraj, S., Iniyan, S., 2006. A review of energy models. Renew. Sustain. Energy Rev. 10, 281-311. https://doi.org/10.1016/j.rser.2004.09.004.

Jimenez, R., 2017. Barriers to electrification in Latin America: income, location, and economic development. Energy Strateg. Rev. 15, 9-18. https://doi.org/10.1016/j. esr.2016.11.001.

Kaldellis, J.K., Kavadias, K.A., Koronakis, P.S., 2007. Comparing wind and photovoltaic stand-alone power systems used for the electrification of remote consumers. Renew. Sustain. Energy Rev. 11, 57-77. https://doi.org/10.1016/j.rser.2004.12.001

López-González, A., Domenech, B., Ferrer-Martí, L., 2017a. Renta petrolera y electrificación en Venezuela : análisis histórico y transición hacia la sostenibilidad.
Cuad. Latinoam. 51, 1-24.

López-González, A., Domenech, B., Gómez-Hernández, D., Ferrer-Martí, L., 2017b Renewable microgrid projects for autonomous small-scale electrification in Andean countries. Renew. Sustain. Energy Rev. 79, 1255-1265. https://doi.org/10.1016/j. rser.2017.05.203.

Massabié, G., 2008. Venezuela: A Petro-State Using Renewable Energies: A Contribution to the Global Debate about New Renewable Energies for Electricity Generation, first ed. VS Verlag für Sozialwissenschaften, Wiesbaden.

MEER, 2017. FERUM - Ministerio de Electricidad y Energía Renovable. [WWW Document]. Fondo Electrif. Rural Urbano y Marg. URL. http://www.energia.gob.ec/ ferum/, Accessed date: 23 January 2017.

MINEM, 2012. Plan Nacional De Electrificacion Rural ( Pner ) Periodo 2013 - 2022 (Lima).

Ministério de Minas e Energia, 2015. Luz para Todos completa 12 anos com 15,6 milhões de brasileiros beneficiados. http://www.mme.gov.br/web/guest/pagina-inicial/ outras-noticas/-/asset publisher/32hLrOzMKwWb/content/luz-para-todoscompleta-12-anos-com-15-6-milhoes-de-brasileiros-beneficiados, Accessed date: 8 February 2017.

Mitra, I., 2006. A renewable island life. Electricity from renewables on small islands. Refocus 7, 38-41. https://doi.org/10.1016/S1471-0846(06)70658-8.

MPPEE, 2013a. Anuario Estadístico 2013: Sector Eléctrico Venezolano. doi:201108DC35.

MPPEE, 2013b. Plan de Desarrollo del Sistema Electrico Nacional 2013-2019 (No. 2013). Caracas lf75220143331944.

Munasinghe, M., 2004. Sustainable development: basic concepts and application to energy. Encycl. Energy 5, 789-808. https://doi.org/10.1016/B0-12-176480-X/ 00441-1.

Nguyen, T.C., Rieger, M., 2014. Community-driven development and social capital: evidence from Morocco. EUI Work. Pap. Max Weber Program xx, 28-52. https://doi. org/10.1016/j.worlddev.2016.10.013.

OECD/EIA, 2010. Energy Poverty: how to make modern energy access universal? Spec. early excerpt World Energy Outlook 52. https://doi.org/10.1016/j.fuproc.2009.10. 007.

OLADE, 2018. Índices Latinoamericanos de Electrificación. Organ. Latinoam. Energía Data. http://www.olade.org/.

Peredo Echazú, R., Jiménez Rivera, H., Gonzáles Flores, J.M., 2010. Plan de Universalización Bolivia con Energía 2010-2025 1-28.

Pereira, M.G., Freitas, M.A.V., da Silva, N.F., 2010. Rural electrification and energy poverty: empirical evidences from Brazil. Renew. Sustain. Energy Rev. 14, 1229-1240. https://doi.org/10.1016/j.rser.2009.12.013.

Pereira, M.G., Sena, J.A., Freitas, M.A.V., Silva, N.F. Da, 2011. Evaluation of the impact of access to electricity: a comparative analysis of South Africa, China, India and Brazil. Renew. Sustain. Energy Rev. 15, 1427-1441. https://doi.org/10.1016/j.rser.2010. 11.005 .

REN21, 2016. Renewables 2016: Global Status Report. (Paris).

SEforAll, 2016. Sustainable Energy for all Strategic Framework for Results | 2016-21. (Vienna).

Shyu, C.W., 2012. Rural electrification program with renewable energy sources: an analysis of China's township electrification program. Energy Pol. 51, 842-853. https://doi.org/10.1016/j.enpol.2012.09.036.

Singh, B., Sharma, J., 2017. A review on distributed generation planning. Renew. Sustain. Energy Rev. 76, 529-544. https://doi.org/10.1016/j.rser.2017.03.034.

Slough, T., Urpelainen, J., Yang, J., 2015. Light for all? Evaluating Brazil's rural electrification progress, 2000-2010. Energy Policy 86, 315-327. https://doi.org/10. 1016/j.enpol.2015.07.001.

Sovacool, B.K., 2013. A qualitative factor analysis of renewable energy and Sustainable Energy for All (SE4ALL) in the Asia-Pacific. Energy Policy 59, 393-403. https://doi. org $/ 10.1016 /$ j.enpol.2013.03.051.

Sovacool, B.K., Drupady, I.M., 2016. Energy Access, Poverty, and Development: the Governance of Small-Scale Renewable Energy in Developing Asia. Routledge.

Tech4CDM, 2009. La Electrificación Rural en ECUADOR. Quito.

Tennakoon, D., 2008. Energy Poverty: Estimating the Level of Energy Poverty in Sri Lanka - Report Submitted to Practical Action South Asia. https://doi.org/10.1007/s13398014-0173-7.2.

Terrapon-Pfaff, J., Dienst, C., König, J., Ortiz, W., 2014. A cross-sectional review: impacts and sustainability of small-scale renewable energy projects in developing countries. Renew. Sustain. Energy Rev, 40, 1-10. https://doi.org/10.1016/j.rser.2014.07.161.

Thirumurthy, N., Harrington, L., Martin, D., Thomas, L., Thirumurthy, N., Harrington, L., 2012. Opportunities and challenges for Solar Minigrid Development in Rural India Opportunities and challenges for Solar Minigrid Development in Rural India. NREL Tech. Rep.

Trochim, W.M.K., Linton, R., 1986. Conceptualization for planning and evaluation. Eval. Program Plann. 9, 289-308.

UN, 2012. Energía Sostenible para Todos: un Programa Mundial de Acción. (New York).

UNDP, 2012. Towards an "Energy Plus" Approach for the Poor: an Agenda for Action for Asia and the Pacific.

Urmee, T., Md, A., 2016. Social, cultural and political dimensions of off-grid renewable energy programs in developing countries. Renew. Energy 93, 159-167. https://doi. org/10.1016/j.renene.2016.02.040.

van Ruijven, B.J., Schers, J., van Vuuren, D.P., 2012. Model-based scenarios for rural electrification in developing countries. Energy 38, 386-397. https://doi.org/10. 1016/j.energy.2011.11.037.

WEC, 2013. World Energy Trilemma: Time to Get Real - the Agenda for Change. World Energy Council, London.

World Bank, 2008. Designing Sustainable Off-Grid Rural Electrification Projects: Principles and Practices, Research Working Papers. https://doi.org/10.1596/18139450-5193. Washington, D.C.

World Energy Council, 2016. World Energy Trilemma 2016 Defining Measures to Accelarate the Energy Transition. (London). 